Review

\title{
On addressing the dual and embedded nature of business and the route towards corporate sustainability
}

\author{
Walter J.V. Vermeulen*, Sjors Witjes \\ Copernicus Institute of Sustainable Development, Utrecht University Utrecht, The Netherlands
}

\section{A R T I C L E I N F O}

\section{Article history:}

Received 11 June 2015

Received in revised form

29 September 2015

Accepted 30 September 2015

Available online 19 October 2015

\section{Keywords:}

Corporate sustainability

Integration

PPP

Organizational culture

Transformation

\begin{abstract}
A B S T R A C T
This article argues for greater attention to be paid to the dual and embedded nature of business. We propose that a more inclusive systemic perspective is needed for the challenge of speeding up the application of 'inclusive' corporate sustainability. The key question is how an on-going upward dynamic of transformative learning cycles can be achieved in practice. The current practice of implementing sustainability management systems, identifying key performance indicators, reporting on sustainability policies and outcomes has a strong focus on the physical dynamics in companies and (in the good cases) in their value chain. In many cases the three dimensions of issues, time and place are only addressed partially. We argue that the academic community needs to pay greater retro- and prospective attention to the social intervention dynamics, introducing checks on the assumed effects of social interventions. In order to achieve a more balanced and inclusive corporate sustainability we need to link levels of the achievement of corporate sustainability goals more strongly with (self-) assessment of the social dynamics in firms and their societal system.
\end{abstract}

() 2015 Elsevier Ltd. All rights reserved.

\section{Contents}

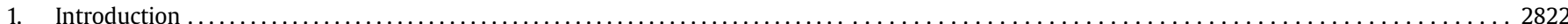

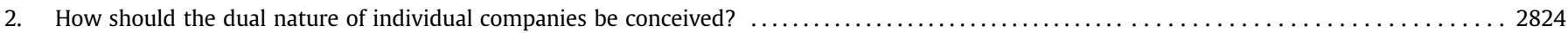

3. How should a long-term ambition for corporate sustainability be set in a widely acceptable way? ......................... 2825

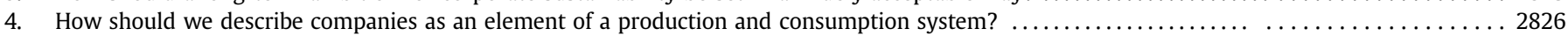

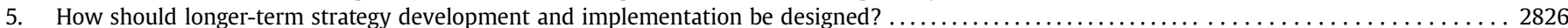

6. How can companies be supported in moving from a limited rational choice approach towards continuous and transformative learning? key imperatives

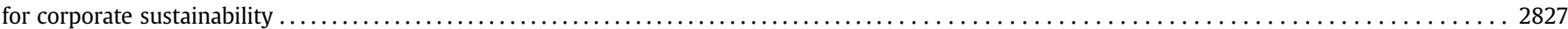

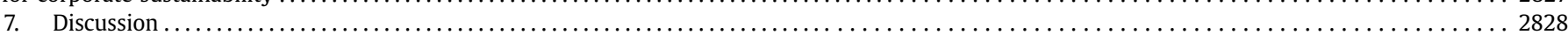

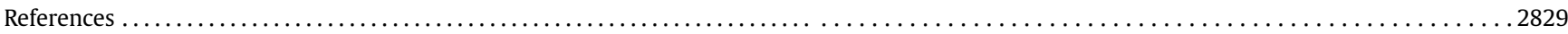

\section{Introduction}

Over the last three decades of pioneering, constructive and critical-evaluative scientific work, many scholars in the field of sustainable production and consumption and especially corporate sustainability have greatly contributed to the adoption of more sustainable practices in business. However, progress is slowing

\footnotetext{
* Corresponding author.

E-mail address: W.J.V.Vermeulen@uu.nl (W.J.V. Vermeulen).
}

down, while the need for greater and faster steps is growing. The key question is how the academic community can further support companies which are already on the road to sustainability, but want to jump to 'all-inclusive' corporate sustainability. Such support may also benefit those companies that are currently stepping on the bandwagon.

In the past, progress was possible with smaller adaptations to regular ways of production and consumption. More recently it has increasingly been argued that more fundamental changes in the modes of production and the way of doing business are needed. 
Such critical thinking about the role of businesses in society has a long history.

Adam Smith is often presented as one of the classical thinkers, promoting in "The Wealth of Nations" the fundamental belief in the invisible hand of the market and the assumption that producers and consumers acting in self-interest are the best for the common wealth. However, Adam Smith himself stressed the need for morally reasonable behaviour in his other classical book "The theory of moral sentiment" (Smith, 1759; Hunt and Lautzenheiser, 2011; Doorman, 2012). In the 18th and 19th century other scholars, like Lauderdale and Rae, were opposed to the belief in unrestricted selfish wealth creation as the best recipe for economic progress (Haney, 1920, pp. 294-302).

From the start of the 20th century scholars have been stressing the need for companies to go beyond merely making profit, by contributing to societal progress in their communities. As did Henry Ford in 1917, defending the reinvestment of profits in plant expansion, arguing the purpose of his company this way: 'To do as much as possible for everybody concerned, to make money and use it, give employment, and send out the car where the people can use it ... and incidentally to make money ... Business is a service, not a bonanza' (Lee, 2008, p. 54). While the discipline of economics developed mostly into a dominant main route of neo-liberal economics and further development of applied fields like business management, logistics, econometrics and accounting, a few smaller critical branches stayed alive, and some emerged recently in the last decades.

In the mid-1950s various scholars again took up this debate about the essence of business activity (Bowen, 1953; Carroll, 1999; Frederick, 1960; Lee, 2008; Moura-Leite and Padgett, 2011) with Davis and Carroll in the 1970s translating corporate social responsibility into new imperatives for business, with Carroll initially focussing mostly on social objectives and philanthropy and Davis stressing both community and environmental impacts (Carroll, 1979, 1987, 1978; Davis, 1975; Frederick, 1994).

From the early 1970s a more elaborate environmental agenda was added to the wish list of doing good by doing business, which resulted in the emergence of many approaches for cleaner production, pollution prevention, industrial ecology, eco-design, ecoefficiency and more. These fields first got their feet on the ground in the late 1980s and early 1990s with successful business pilot projects (Allen and Rosselot, 1994; Baas, 1998; Burns, 1999; Cagno et al., 2005; Gallup and Marcotte, 2004; Granek, 2011; Ochsner et al., 1995) which were taken as examples and used to promote wider implementation (Baas, 2007; Bartholomew et al., 2008; Durfee, 1999; Keijzers, 2000; Kuehr, 2007; Miller et al., 2008; Stevenson, 2004; United Nations Environment Programme, 2007; van Berkel, 2007).

In the 1990s we saw a revival of the concept of corporate social responsibility, both in the academic world (Burke and Logsdon, 1996; Carroll, 1991; Porter, 1991) and in politics and the market (European Commision, 2006; European Commission, 2001; Holme and Watts, 2000; Petkoski and Twose, 2003; Watts and Holme, 1998). This started a development of moving CSR away from philanthropy towards what nowadays is called creating shared value (Chouinard et al., 2011; Porter and Kramer, 2006, 2011a).

During the last quarter century impressive improvements in eco-efficiency have been achieved in at least a limited number of countries. Some of the major classic types of pollution at national level have been impressively reduced in north-western European countries. Recycling rates for some materials have gone up to $>80 \%$ in some countries (EEA, 2015). But many countries both in the North and in the South still need to make major steps. In the same period, in many sectors, manufacturing companies have outsourced production facilities towards developing countries aiming for cost reduction (Dicken, 2015) and lean environmental regulations, as stated in the disputed 'pollution haven' hypothesis (Bu et al., 2013; Cole, 2004; Eskeland and Harrison, 2003; Grether et al., 2012; Levinson and Taylor, 2008).

However, the process of globalisation also implies that a globally networking civil society is witnessing these developments and they increasingly put pressure on multinational companies to improve their social and environmental performance (Christmann and Taylor, 2002; Haddock-Fraser, 2012; Rourke, 2005; Vermeulen, 2015).

At the same time we see a rapidly increasing urgency to create a clean, circular and renewable energy-based economy, partly due to the aspiration to Western lifestyles of the fast growing middle classes in emerging economies (UNEP, 2011a).

Taking this to the company level, it poses new and more inclusive challenges for adapting the day-to-day business routines. Large internationally operating companies feel this pressure more strongly than locally oriented SMEs (Vermeulen, 2015). But even in the case of SMEs most companies are somehow embedded in larger production and consumption systems with a global span (Kerr, 2006).

The historical lines of critical thought on the role of companies in society are now revived in the new debates on corporate sustainability. The various pleas for corporate sustainability are heard from diverse corners, each stressing their own specific perspective, which is often linked to a specific disciplinary background. This disciplinary divide has its advantages of in-depth analysis, but also the common drawback of partial paradigmatic blindness. In this article we propose an inclusive systemic perspective. This is useful both for the academic analysis of the progress being made as well as for direct support to corporate strategies in implementing and further integrating their sustainability policies.

Our starting point is the observation that individual businesses should be seen as a phenomenon with a dual nature and as a single element embedded in a larger societal system. As with 'two sides of a coin', the 'dual nature' refers to the simultaneously existing physical dynamics and social dynamics in businesses. This dual physical and social nature should be taken into account both when looking at the internal dynamics in businesses and when looking at the relations of businesses with their outside world. Taking this metaphor a bit further, any separate coin will only have value due to the monetary system in which it is embedded. In this way also any single company can only successfully exist due to it being a part of far larger production and consumption systems (with the directly related actors in the value chain), which in turn are embedded in the larger societal system, including civil society, governments, knowledge producers and last but not least the wide diversity of individuals in their various roles. A company will only have its value if it maintains a positive symbiosis with this societal environment.

In our opinion many approaches promoting corporate sustainability poorly address this dual and embedded nature with limited rational choice approaches. These approaches may yield some short-term successes, but eventually will run into systemic barriers.

Taking the dual and embedded nature of businesses as a starting point enables us to address a number of key questions for the implementation of corporate sustainability.

a) How should the dual nature of individual companies be conceived?

b) How should a long-term ambition for corporate sustainability be set in a widely acceptable way?

c) How should we describe companies as an element of a production and consumption system? 
d) How should longer-term strategy development and implementation be designed?

e) How can companies be supported in moving from a limited rational choice approach towards continuous and transformative learning?

\section{How should the dual nature of individual companies be conceived?}

The reason for the existence of companies is that they satisfy certain needs of individuals or groups in society by creating and selling certain products or services. As such they are an element in a wider physical production and consumption system (which in economic terms is called a value chain and in environmental terms a product life cycle). Crucial to the description of the phenomenon of a company is on one side the physical reality of products or services being produced and offered and the physical, chemical and mechanical processes needed for that, with their physical impacts on the wider environment and ecology. Equally crucial are social dynamics: internally in the company and externally in its outside relations with the social world, both in terms of economic market processes (supply chain, customers, reverse logistics, financing etc.) and social relations with other stakeholders (local authorities, neighbours, NGO's, media etc.).

In the history of the last centuries companies have proven to be able to permanently innovate and increase the efficiency of production, to some extent on their own, but mostly in collaboration with the surrounding societal system, including governments, knowledge producers, civil society and creative individuals. Such innovations may concern both technological processes and products as physical realities, as well as the social dynamics in the forms of collaboration, applied business models and institutional settings for production.

Companies normally operate in a fairly static mode. These are the fixtures in ways of getting products and services on the market based on proven successes: day-to-day routines and standardised procedures in businesses, the ingrained management styles and culture, the workers' ethos, all locked in by fixed capital investments. This gives individuals in companies at all levels a certain sense of security in a constantly threatening and changing outside market and wider world. Maintaining this static mode makes sense for the short term, relying on one's proven approaches. It only gives room for small steps and incremental changes, which is a safe short-term strategy for many.

However, in the outside world change is always around and with the growing global population and its increasing physical needs, the speed of change in the outside world of companies will only increase.

For companies, this implies the need to regularly step out of their comfort zone and unfreeze institutionalised routines and procedures (Lozano, 2007; Maon et al., 2009). This is needed anyway in a permanently developing international market. But overall the still widespread unsustainable practices and resulting continuing and increasing global threats (Haberl et al., 2011; Parris and Kates, 2003; Rockstrom et al., 2009) require companies to regularly re-orient their long-term future and rethink their current business position and strategy. Therefore the organisation of continuous change and transformative learning is key to both business success and progress towards a sustainable society (Bebbington et al., 2007; Howie and Bagnall, 2015; Kitchenham, 2008).

Rational planning processes and continuous improvement have been introduced as key concepts since the late 1980s, with the application of plan-do-check-act approaches in environmental management systems (Curkovic and Sroufe, 2011; Delmas and Toffel, 2008; Delmas, 2002; Melnyk et al., 2003; Moen and
Norman, 2006; Morrow and Rondinelli, 2002; Pojasek, 2012; Steger, 2000) and in many of the proposed step-wise approaches for cleaner production, zero waste, industry ecology, the natural step, green chemistry, design for sustainability, blue economy, cradle to cradle et cetera (Baas, 1998; Braungart et al., 2007; Burns, 1999; Graedel, 1996; Kuehr, 2007; Ochsner et al., 1995; Pauli, 2010; Vermeulen, 2006). Many firms worldwide have been adopting and adapting these approaches (more than 300,000 companies certified under ISO 14001 (ISO, 2004) in 2013 (ISO, 2013)), sometimes as single loops, but often as repeated loops, permanently identifying and implementing smaller or larger improvement projects (Maon et al., 2009; von Ahsen, 2014). However, organisations always need to make choices on what is affordable for the short-term, restricted by available budgets, constrained in the context of their current day market prices. In this context, repetitive learning cycles tend to get refrozen into new administrative routines, to a level just enough to satisfy external auditors, in response to demands posed by key value chain stakeholders (Calcott, 2010; Tinsley, 2002; Zorpas, 2010). In recent years various companies with good track records in environmental management came to us with questions on how to break out of these renewed routines and make a jump to more 'inclusive' corporate sustainability (Bootsma et al., 2014). In our post-graduate programs on sustainable development and corporate sustainability we worked with student groups in dozens of companies, successfully addressing such strategic questions (Bootsma et al., 2014).

Most of the methodologies available for implementing (elements of) corporate sustainability (or their predecessor's concepts in the environmental field) include some form of describing current impacts and a comparison with (long-term) future societal needs (Szekely and Knirsch, 2005). Companies need a very good reason to start to unfreeze routines every now and then, and be motivated to apply systematic forms of back-casting: goal setting, comparing goals with actual practices, resulting in scenario development and implementation. Various scholars propose to refer to long-term oriented motives (Hart and Milstein, 23; Porter and Kramer, 2011b), going beyond direct pay-offs of environmental projects (Burke and Logsdon, 1996; Cagno et al., 2005; Gravitis, 2007; van Berkel, 2007).

To start with goal setting: in practice, for most companies, the long-term challenges and threats addressed with the concept of sustainable development are not very clear at all, thus hampering the goal setting. This is partly the result of the on-going, open and divergent discourses on what is needed for sustainable development. This divergence partly has its roots in the endless debates about the "correct" meaning of the concept of sustainable development in and between academic disciplines. It is also partly rooted in the same tendency to disagree in the political arena. We also see this common practice to compete by means of different framings of the concept in the market arena. These three processes of divergence are mutually reinforcing, and do not help companies in making substantial steps in the right direction, especially the smaller ones.

Defining 'corporate sustainability' as being about individual companies implementing strategies to achieve sustainable development (Baumgartner and Ebner, 2010; Dyllick et al., 2002; Eccles et al., 2014; Hahn et al., 2015; Montiel, 2008; van Marrewijk, 2003a), the first step would be to support companies in making sense of sustainable development and what that implies for them. As a second step it requires a proper view of the current dual and embedded nature of one's company and when that is known, as the third step having a proper view on externally available and/or still to be developed innovative ways of satisfying societal needs with the products or services one can offer. Let us look at the first step. 


\section{How should a long-term ambition for corporate sustainability be set in a widely acceptable way?}

The first step requires finding a way through the cacophony of opinions. These range from, on one side, the minimal position of just complying with regulatory requirements (which, in itself, is confusing due to contradictions and diversity in and between regulatory regimes in the $>180$ nations), via a wide variety of opinions available in the scientific, political and market arenas (Du Pisani, 2006; Robinson, 2004) to, on the other side, some extreme positions of various fundamentalists in civil society, and academics taking positions which may even almost exclude the mere existence of businesses and modern mankind from the picture of Gaia (Callicott, 2005; Lovelock, 2003).

How can one still help companies find their way? There is a way out of this: despite this noisy cacophony in the intellectual, political and market arenas, discourses on the supranational level have resulted in a fairly well supported rough consensus about the core elements of the concept of sustainable development. Some sub-elements may still need some refining, some other key elements may still be further completed with additional subelements, but a core-structure exists and is widely being worked with.

Pragmatic choices need to be made. What is the contribution to be made: continue endlessly impeaching the concept, or work with the well-supported rough consensus and get it to be further finetuned by exposing it to communities of practice?

For the last purpose, we have good experiences with presenting the concept of sustainable development in the context of discourses on vision and strategy development as a somewhat limited Rubik's Cube (not $3 \times 3 \times 3$, but $3 \times 2 \times 2$ boxes, see Fig. 1 ), combining the issues dimension (PPP), with the time dimension (now and then) and the place dimension (here and there).

The issues dimension summarized in the triple-P refers to the various sustainability issues, or in order words: the three fields of negative internal and external impacts of production and consumption systems, all three being roughly equally important. The first $\mathrm{P}$ for planet is about ecological threats, which can be organised in various ways. The second $P$ for people refers to the direct threats and obstructed development potentials and opportunities for individuals that are linked to any of the parts of full production systems. And the third P refers to prosperity, which reflects the developmental goal at society level in the concept of sustainable development and requires a well-functioning societal system, where companies create shared value and prosperity in the communities they serve (European Commission, 2002; Halonen and Mkapa, 2004; Hammond, 2006).

The time dimension is embedded in the debate on sustainable development via the principle of generational equity, requiring us to pass on our habitat to future generations, offering them the same opportunities that we have (referring to the famous, most cited quote of World Commission on Environment and Development, 1987, p. 41). ${ }^{1}$ As an essential imperative for corporate sustainability strategy development this implies two key activities: both taking a long-term perspective focussing on radical changes, which require time, while also starting with activities which can be implemented tomorrow rather than next year (Bansal and DesJardine, 2014; Lozano, 2008; Tukker et al., 2008). Thus companies should engage in identifying probable future trends in their markets and anticipate the design of pathways for long-term adaptation to create positive impacts on

\footnotetext{
1 Sustainable development is development that meets the needs of the present without compromising the ability of future generations to meet their own needs.
}

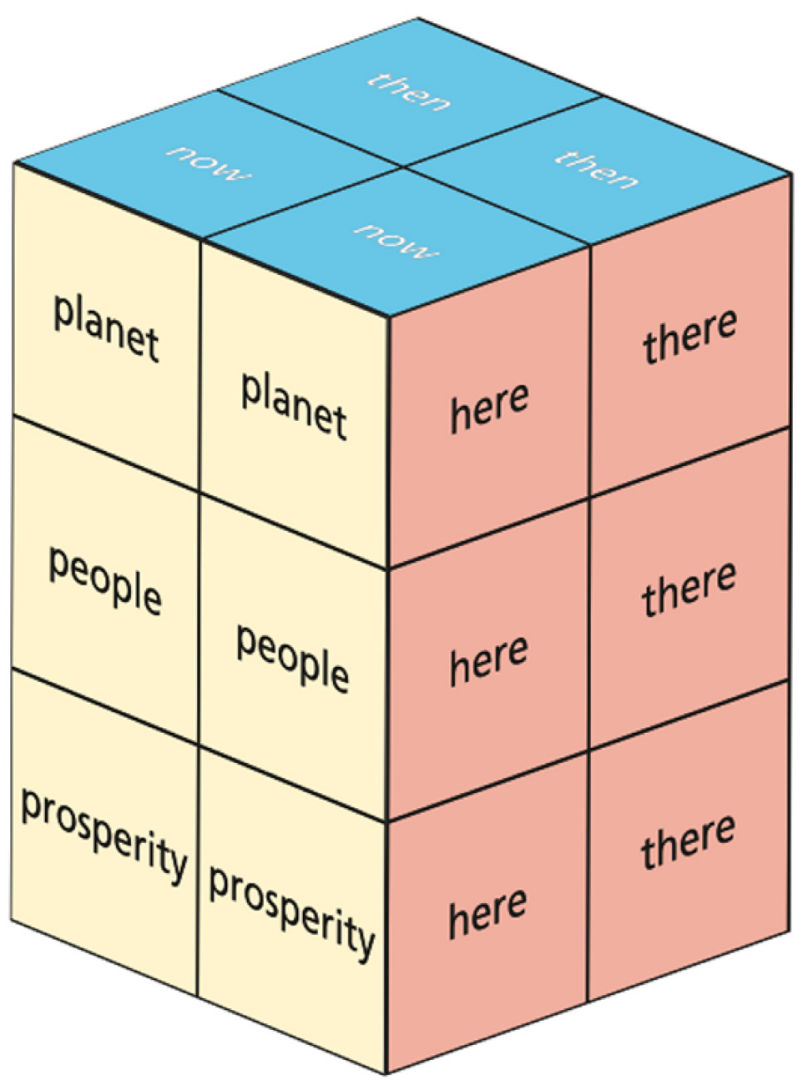

Fig. 1. Three dimensions of the concept of sustainable development: issues, time and place, containing $3 \times 2 \times 2$ boxes.

society and ecology. But the long-term approach should not prevent them from implementing strategies with direct benefits. These are especially needed to secure the commitment of stakeholders.

The place dimension is crucial for the systemic approach, stressing the links of any production or consumption activity via value chains with the distribution of negative environmental, social and prosperity impacts elsewhere during the full life cycle of products or services (Chouinard et al., 2011; Dicken, 2015; Lenzen et al., 2012; Porter and Kramer, 2011b).

For the issue dimension we can substantiate our claim about the availability of a well-supported rough consensus on the core elements of the concept of sustainable development, by referring to various widely supported initiatives on the supranational level, linked in various communities of practice of implementing and assessing (corporate) sustainability.

The first practice is the wide application of the GRI guidelines for reporting. Their reporting standards contain a combination of issue descriptors and descriptors related to management processes. Among the world's 250 largest companies $82 \%$ refers to the GRI guidelines in 2013 (KPMG, 2013, p. 11). More recently the ISO 26000 guideline for social responsibility (ISO, 2010) has been increasingly accepted (ISO and GRI, 2014). The issue descriptors in both approaches can be used here to identify the issues addressed. However, GRI focuses on showing progress in performance rather than describing long-term target levels.

The second practice is the rapid take-up of voluntary sustainability standards in international trade. Two supranational organisations active in this field (WTO-ITC and ISEAL Alliance) have recently developed guidelines and reviews (ISEAL Alliance, 2013; 
ITC, 2011; see also Potts et al., 2014) that give a comprehensive overview of the planet, people and prosperity related issues. Here the focus is more on the issues and means and practices to be applied. Again these issues would need to be translated into longterm target levels.

A third source for the rough consensus is a selection of the best examples of indicator-sets for measuring sustainability at the national level. Here we also witness a wide and diverse community of practice. The International Institute of Sustainable Development is providing an online platform (the Compendium of Sustainable Development Indicator Initiatives) giving access to this variety of sustainability indicators (IISD, n.d.). A comparative analysis of the content and methodological approaches of these indicators also allows the identification of a common ground in the key descriptors of the three sustainability issues.

Combining these three sources results in short lists of relevant issues, which are robust enough for companies who are willing to make the next steps and identify their long-term strategy. It would also be essential to identify proper attention to the inter-linkages between the various issue elements (Lozano and Huisingh, 2011). At this stage we are merely interested in presenting a comprehensive overview of relevant issues, in order to prevent companies from overlooking issues that later on would still need to be addressed. Of course this will lead to debates about trade-offs between the various elements of the sustainability issues and priority setting, but this is to be addressed in the specification of companies' policy plans.

For each of the challenges of reducing specific impacts under the triple-P issues, the second dimension of time implies that companies connect their long-term expectations on these threatening impacts to the analysis of their own current (production) practices; what is the link with what one's company does, what goal does one need to set (in various time scales) and what options does one have to improve short and longer term improvements (Holmberg and Robert, 2000)? For this, long-term expectations and projections are produced and renewed constantly (to name a few: Leisinger and Bakker, 2013; UNEP, 2011a; WBCSD, 2010a). This may result in debates about their reliability and their completeness, but the constant underlying message is that substantial changes will be taking place and for any company it is wise to anticipate these. From this perspective companies would need to formulate their own longterm target levels, which may be adjusted in due course. If companies develop such long time perspectives, they may also more easily make sense of the abundance of possible key performance indicators available in literature and the practices of consultancy.

This also requires an on-going reflection on what the company is doing in its full functioning as a part of a larger production system; of global production networks (Dicken, 2015, pp. 54-72, 280-281; Vermeulen, 2015, 2010). This system perspective links directly to the third dimension of place: any product has distributed impacts over its geographical value chain (Lenzen et al., 2012b; Nijdam et al., 2008).

When working from the perspective of any individual firm, the three dimensions of sustainable development: triple-P issues, time and place are always essentially interconnected. Most important here is to stress that with the sustainability challenges ahead, structural changes are needed in how our production and consumption system functions. This calls for more than incremental technological improvements; for societal transformations in the sociological sense of changing institutions and structures of economic behaviour (ISSC and UNESCO, 2013, p. 101; Sewell, 1992) both inside the firm and in the wider societal system. This brings us to the next question.

\section{How should we describe companies as an element of a production and consumption system?}

Taking the dual and embedded nature of companies again as starting point, we need to combine the knowledge developed from various disciplines, as mentioned in the first section. Taking a position in corporate sustainability requires an analysis of the physical dynamics inside the specific company in relation to its full physical product life cycle, as well as an analysis of the social dynamics. Both dynamics need to be addressed inside and outside the specific company. This includes the social impacts in the full product life cycle and the appropriateness of the economic practices in the transactions with various stakeholders throughout the value chain. Described in this way it contains various elements. For each element separate tools are available (for various overviews see Glavic and Lukman, 2007; Lozano, 2012; Robert, 2000; Robert et al., 2002), but they need to be applied in a systematically integrated way.

After two decades of using environmental management systems, many companies have got used to monitoring their progress, because -in principle-in applying ISO14001 and comparable systems they have signed up to continuous improvement. But in practice this monitoring of progress has a very limited application (Delmas, 2003, p. 38; MacDonald, 2005, p. 631). In the best cases various key performance indicators on some of the physical dynamics are available to decision-makers in companies (Birkin et al., 2009, p. 287; Boons and Ludeke-Freund, 2013, p. 15; Yin and Schmeidler, 2009). However, in contrast to that, retrospective self-reflection of the social dynamics inside the company and with its connections with the outside world is hardly being practised (Aguinis and Glavas, 2012, pp. 955-957; Baumgartner, 2014, p. 259).

This is actually quite remarkable. With the immense sustainability challenge ahead (section 1 ), the necessary social dynamics inside firms and between stakeholders are created and affected by the implementation of the various suggested sustainability strategies, which will result in their improved physical performance. A lack of proper understanding of this is like driving a car at night with the lights off and no hands on the steering wheel. So, to enable significant change, companies need to make regular self-reflections of their dual and embedded nature, linking how they function in their social dynamics with what they achieve in their physical dynamics in their full production and consumption system.

\section{How should longer-term strategy development and implementation be designed?}

Based on a self-reflective analysis companies need to identify their room for innovation. For this process search directions are needed. One might want to get such directions from governments, if they have formulated long-term targets, such as $40 \%$ reduction of carbon emissions by 2030 (EU) or $80 \%$ by 2050 (UK). But here again we repeat the observation that regulatory regimes as seen in an international context, by nature, are confusing due to contradictions and diversity in and between nations, so this yields confusing instructions. This is also why open-minded and two-directional stakeholder engagement with societal stakeholders is indispensable (European Multistakeholder Forum on CSR, 2004, p. 110; Hart and Milstein, 2003, p. 61; Polonsky and Jevons, 2009, p. 340). Search directions can best be identified with these societal actors.

However, the visions for the long term are not as unclear as public debates may suggest. Just as with the operationalization of sustainable development, here we also have supranational networks and initiatives, as mentioned above, that provide a widely supported set of main routes for technical and social innovation. 
Combining these various suggested sources for long-term visioning can be summarised in five key search directions for societal transformations (Vermeulen, 2015):

- towards climate control and a renewable energy based society;

- towards a circular economy reducing its dependency on virgin resources, based on circular resource use and dematerialization;

- towards neutral or positive impact on biodiversity;

- towards an economic system creating shared triple value, including community well-being and poverty oriented production approaches, such as bottom of the pyramid (BoP) (Schrader et al., 2012);

- towards equitable market and governance institutions at all levels, addressing institutional causes of unsustainability in the globalized economy (UNEP, 2011b).

Available literature supplies sufficient challenging examples for each of these key search directions to inspire both large and smaller firms.

There is also a wide variety of suggested approaches and methods to kick off strategy formulation activities within firms. As observed above, companies applying repetitive plan-do-check-act cycles tend to lose momentum and the level of improvement in each next cycle of continuous improvement reduces. Lack of internalisation into the company's culture, value system and into communications with its societal stakeholders is often the core reason for this 'jamming' of sustainability strategies. Plan-docheck-act cycles may be repeated, but suffer from a tendency of diminishing returns (Baumgartner, 2014, p. 260). In our opinion, combining our observations of what is addressed in scientific literature and what we see in our interactions with companies, this is linked to weak integration and weak orientation on the longterm and long-distance challenges (two of the three dimensions in the cube in Fig. 1).

In analysing the practice of corporate sustainability and in supporting key actors in the field, we need to take a longer time perspective, not looking at short-term kick-off projects, but at enabling accelerating change processes, where each next cycle gears up its impact: transformative change.

\section{How can companies be supported in moving from a limited rational choice approach towards continuous and transformative learning? key imperatives for corporate sustainability}

In our opinion companies and change agents who are supporting companies and the academic community share a common challenge here. If we take the need for a transformative change as the challenge to speed up the application of 'inclusive' corporate sustainability, and we agree on the essential dual and embedded nature of business, then the key question is how an on-going upward mechanism of transformative learning cycles can be achieved in practice. The current practice of implementing sustainability management systems, including the identification of key performance indicators and reporting on sustainability policies and outcomes often has a strong focus on the dynamics of the physical production processes in companies addressing and (in the good cases) in their value chain. They may also address the social impacts of value creation (related to workers inside the company, the neighbourhoods and - if taken in a supply chain perspective - of supplier companies). But in many cases the three dimensions of issues (PPP), time and place are addressed only partially. Simultaneously however, the self-reflection on whether applied interventions work as expected is often limited. The social dynamics related to the social interventions aiming at reducing negative direct and indirect impacts are largely ignored and the analysis of the links between the social dynamics and physical dynamics are underexplored.

In transformative change the learning cycle should be seen as a constantly rotating plan-do-check-act wheel, which should be riding up the mountain quickly enough. Such transformative change can only be effective if it is a constant process self-assessment by the company. In doing this it is essential to explore the company's social intervention dynamics and their links to the level of success in affecting the dynamics adjusted physical and social impact creation: the value creation practices. This finally needs to result in improving the effectiveness of efforts of reducing negative impacts and shifting towards positive effects in the three issue areas of the triple-P, both here and there and both in the short term and the long term.

In our view a corporate sustainability theory of change of firms embedded in societal systems needs to explicitly link the social intervention dynamics as essential in the pathway from beliefs, values, needs and motives via repetitive learning to successfully implementing social and technical innovations in the firm's societal systems.

For companies, this implies a management strategy with permanent feedbacks between four elements:

a. on-going goal re-orientation, addressing the three sustainable development dimensions (3P issues, time and place);

b. longitudinal analysis (retro- and prospective) of the general social dynamics in the firm and the social dynamics of introducing interventions;

c. longitudinal analysis (retro- and prospective) of the physical and societal impacts of introducing interventions aiming at the triple issue fields (PPP);

d. linking the results of the analysis of social dynamics to the impacts in physical and social realm, and translating this to goalre-orientation and adjusted social and technical strategies.

These essential feedbacks are schematically represented in Fig. 2. The feedback X refers to the reflection on whether social interventions applied in the organisational structure and culture

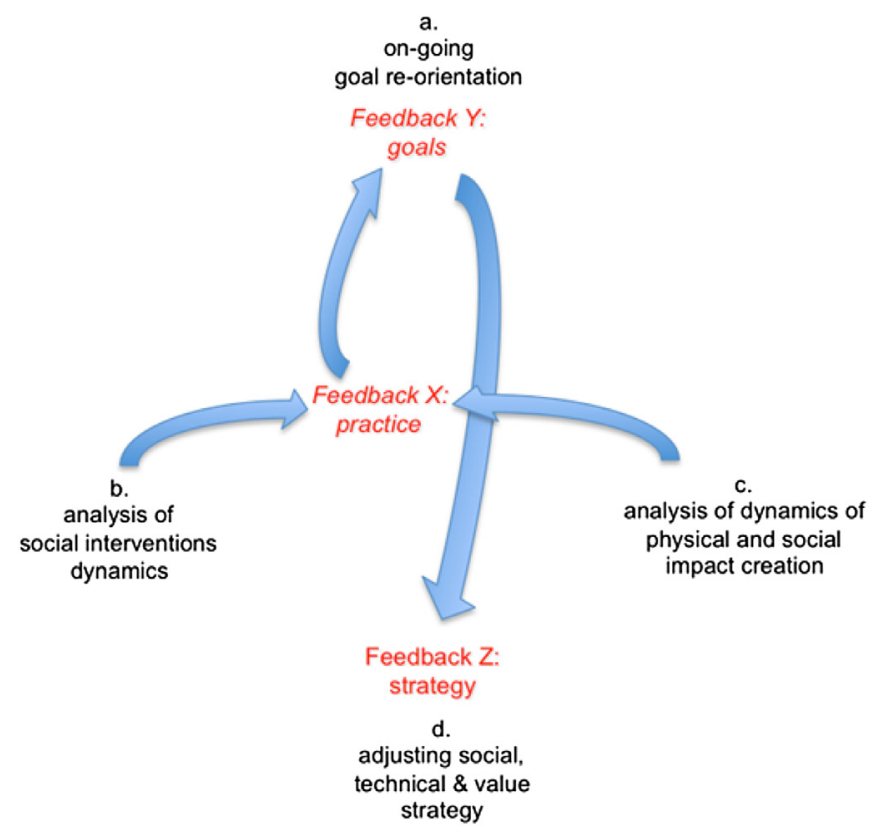

Fig. 2. Permanent feedbacks between 4 elements of transformative change. 
and in the collaboration with value chain partners do in fact result in the assumed effects on the performance in the physical and societal realm. Is the 'theory of change' actually working and what other social interventions could be effective in the specific organisation reviewed?

The feedback Y refers to the refining of the company's mission and goals based on the reflections under feedback X. At this stage the required permanent monitoring of essential changes in the context of the company and the internal lessons learnt on what works and what does not work need to be integrated. This can result in a reformulated, more challenging vision or mission document and needs to be translated in adjusted KPIs (Key Performance Indicators).

Feedback $\mathrm{Z}$ then refers to adjusted strategies both in terms of new projects enabling the attainment of the physical and social targets and the type of social interventions planned to achieve these. This includes making explicit assumptions about the 'theory of change', which can be tested in a next phase.

Feedback X, Y and Z are interdependent: the learning about the causal links between the social and physical dynamics (feedback X), the readjustment of corporate goals (feedback Y) and the integration of these first two learning cycles into the learning about interventions in the company's processes and its people in order to comply with the CS vision.

\section{Discussion}

It is essential that approaches to corporate sustainability include such a permanent self-reflective learning process inside the company. Corporate sustainability scholars from different academic and geographic backgrounds have recently been proposing approaches for the implementation of corporate sustainability. Looking at these we can review to what extent these approaches stress such selfreflexive feedbacks. In Table 1 we present this review.

In many cases the reasoning starts from the perspective of stakeholder engagement and the need to respond to the societal context (Asif et al., 2011; Azapagic and Perdan, 2005a; Cramer, 2005a; Maon et al., 2009). Some stress the need of taking longterm challenges posed by sustainability sciences as a starting point to elaborate a long-term vision (Baumgartner, 2014, p. 264; Searcy, 2014, p. 9).

Most of these approaches combine using a plan-do-check-act cycle of continuous improvement in one or another way with widening the scope of sustainability issues to be addressed. Goal formulation and performance measurement are common elements, as well as communication with external stakeholders, both in the initial phase of issue identification and after the check phase, showing the achievements. Various authors present typologies of firms with different attitudes and cultures towards corporate sustainability, which would then require case-specific implementation approaches (Baumgartner and Ebner, 2010, p. 82; Baumgartner, 2009, p. 104; Hahn and Scheermesser, 2006, p. 159; Linnenluecke and Griffiths, 2010, p. 359). Many of the approaches are (implicitly) presented as a first start to implementing corporate sustainability, which is not helpful if applied to companies that have a long history of environmental and/or corporate social responsibility policies. In contrast a few scholars explicitly present their approach as starting with reflecting on earlier achievements (Cramer, 2005a) and 'unfreezing' existing practices (Maon et al., 2009).

We have been looking how and to what extent these scholars propose transformative learning with the three types of feedbacks we just discussed. We see that in most approaches the registration of achieved improvements of physical and social impacts of the value creation is well addressed. The (re-)formulation of mission and goals does in most cases include a balance between environmental and social impacts, taking into account the working conditions in the wider supply chain. Some articles take a more limited view on this (see Azapagic and Perdan, 2005a, p. 105; Baumgartner and Ebner, 2010, p. 79).

In section 3 we referred to the PPP, taking the third "P" beyond the perspective of 'profit' (as: 'firms still need to make profit while addressing sustainability'), towards a reflection on how companies create shared value and prosperity in the communities they serve. This 'prosperity' perspective is far less present in the current writings. Some authors do take this wider perspective explicitly as part of their approach (Cramer, 2005b, p. 585; Epstein and Buhovac, 2010, p. 306; Hahn et al., 2015, p. 302; Linnenluecke and Griffiths, 2010, p. 358), while others still apply the narrow framing (Asif

Table 1

Review of recent literature on corporate sustainability integration approaches and elaboration of the CS management elements and 3 feedbacks.

\begin{tabular}{|c|c|c|c|c|c|c|c|c|c|c|}
\hline \multirow[t]{2}{*}{ Main researchers with papers } & \multicolumn{2}{|c|}{$\begin{array}{l}\text { Analyse internal } \\
\text { intervention social } \\
\text { dynamics }\end{array}$} & \multicolumn{2}{|c|}{$\begin{array}{l}\text { Analyse achieved } \\
\text { physical \& social } \\
\text { impacts in value } \\
\text { creation }\end{array}$} & \multirow[t]{2}{*}{$\begin{array}{l}\text { Feedback X: } \\
\text { Practice }\end{array}$} & \multicolumn{3}{|c|}{$\begin{array}{l}\text { On-going goal } \\
\text { re-orientation }\end{array}$} & \multirow[t]{2}{*}{$\begin{array}{l}\text { Feedback Y: } \\
\text { Goals }\end{array}$} & \multirow[t]{2}{*}{$\begin{array}{l}\text { Feedback Z: } \\
\text { Strategy }\end{array}$} \\
\hline & $\begin{array}{l}\text { Retro- } \\
\text { spective }\end{array}$ & $\begin{array}{l}\text { Pro- } \\
\text { spective }\end{array}$ & $\begin{array}{l}\text { Retro- } \\
\text { spective }\end{array}$ & $\begin{array}{l}\text { Pro- } \\
\text { spective }\end{array}$ & & $3 P$ & Time & Place & & \\
\hline $\begin{array}{l}\text { Hahn, T. } \\
\text { et al. (Hahn and Scheermesser, 2006; Hahn et al., 2015) }\end{array}$ & - & $\mathbf{V}$ & $\mathbf{V}$ & $\mathbf{V}$ & $\mathbf{V}$ & PPP & $\mathbf{V}$ & $\mathbf{V}$ & (.) & (.) \\
\hline $\begin{array}{l}\text { Baumgartner et al. (Baumgartner and Ebner, 2010b; } \\
\text { Baumgartner, 2014, 2009) }\end{array}$ & $(\mathrm{v})$ & $\mathbf{V}$ & $\mathbf{V}$ & $\mathbf{V}$ & $\mathbf{V}$ & $\mathrm{PP}(\mathrm{P})$ & $\mathbf{V}$ & $\mathbf{V}$ & - & - \\
\hline Searcy \& Asif, M. et al. (Asif et al., 2011; Searcy, 2014, 2011) & $(\mathrm{v})$ & $\mathbf{V}$ & - & $\mathbf{V}$ & $\mathbf{V}$ & $\mathrm{PP}(\mathrm{P})$ & $\mathbf{V}$ & $\mathbf{V}$ & $(\mathrm{v})$ & \\
\hline Schaltegger et al. (Figge et al., 2002; Schaltegger et al., 2013) & - & - & - & - & (.) & $\mathrm{PP}(\mathrm{P})$ & - & $\mathbf{V}$ & - & - \\
\hline $\begin{array}{l}\text { Linnenluecke et al. (Linnenluecke and Griffiths, 2010; } \\
\text { Linnenluecke et al., 2009) }\end{array}$ & $\mathbf{V}$ & $\mathbf{V}$ & - & $(\mathrm{v})$ & $\mathbf{V}$ & PPP & - & - & (.) & (.) \\
\hline $\begin{array}{l}\text { Lindgreen \& Maon et al. (Lindgreen and Swaen, 2010; } \\
\text { Lindgreen et al., 2010; Maon et al., 2009) }\end{array}$ & - & $\mathbf{V}$ & - & $(\mathrm{v})$ & $\mathbf{V}$ & $\mathrm{PP}(\mathrm{P})$ & - & - & $\mathbf{V}$ & $\mathbf{V}$ \\
\hline $\begin{array}{l}\text { Cramer et al. (Cramer, 2005a, 2005b; Van der Heijden et al., } \\
\text { 2010) }\end{array}$ & $\mathbf{V}$ & $\mathbf{V}$ & $\mathbf{V}$ & $\mathbf{V}$ & - & PPP & $\mathbf{V}$ & $\mathbf{V}$ & $\mathbf{V}$ & - \\
\hline $\begin{array}{l}\text { Azapagic et al. (Azapagic and Perdan, 2005b; Azapagic, } 2004 \text {, } \\
\text { 2003) }\end{array}$ & - & (v) & - & $\mathbf{V}$ & $\mathbf{V}$ & $\mathrm{PP}(\mathrm{P})$ & $(\mathrm{t})$ & $\mathbf{V}$ & - & - \\
\hline Marrewijk et al. (van Marrewijk, 2004b, 2003b) & $\mathbf{V}$ & $\mathbf{V}$ & - & - & $(\mathrm{v})$ & $\mathrm{PP}(\mathrm{P})$ & $\mathbf{V}$ & $\mathbf{V}$ & - & - \\
\hline Epstein et al. (Epstein and Buhovac, 2010; Epstein and Roy, & $\mathbf{V}$ & $\mathbf{V}$ & $\mathbf{V}$ & $\mathbf{V}$ & $\mathbf{V}$ & PPP & $\mathbf{V}$ & (v) & $\mathbf{V}$ & - \\
\hline
\end{tabular}

2001)

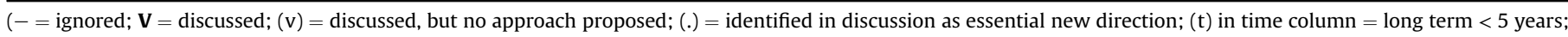
PPP = sustainability issues discussed with wider perspective on 'prosperity'; $\mathrm{PP}(\mathrm{P})=$ sustainability issues discussed with narrow perspective on 'profit' (see section 3$)$ ). 
et al., 2011, p. 355; Azapagic and Perdan, 2005a, p. 105; Schaltegger et al., 2013, pp. 219-220).

For the time dimension we see a mixed picture. In some cases the time dimension is presented in a fairly narrow frame, with four to five years presented as 'long-term' planning' (Azapagic and Perdan, 2003, p. 308). Others explicitly take a longer term perspective applying back casting methodologies and including prospects of long term global trends, which is essential in sustainability thinking (Baumgartner, 2014, p. 263; Hahn et al., 2015, p. 304). This way of thinking has been elaborated by the World Business Council for Sustainable Development in 2010 and is available for all (WBCSD, 2010b; WBCSD et al., 2010).

Most approaches pay attention to analysing current physical and social impacts connected to value creation, either with quantitative methods (e.g. LCA) (Azapagic and Perdan, 2005a, p. 107) or qualitative methods and translate this into reduction targets (Cramer, 2005a; Figge et al., 2002). Some approaches with a focus on the social dimension take this part for granted (Linnenluecke et al., 2009; van Marrewijk, 2003b).

In reviewing the progress made, a few of the scholars explicitly address the need for retrospective analysis of the achieved physical and social impacts, which is seen as essential to understand success and failures in the implementation of strategies (Epstein and Roy, 2001, p. 600; Hahn et al., 2015, p. 304). Baumgartner stresses the need to include analysis of "socially constructed, historically influenced, soft, but relatively stable organizational culture" and refers to available methods which enable such analysis over time, but do not further develop this element in their approach (Baumgartner, 2014, pp. 264-265). Epstein and Buhovac state that "it is through a mix of leadership, strategy, structure, as well as hard and soft management systems, that sustainability can be implemented and measured successfully", but they do not elaborate how the soft systems and leadership could be measured retrospectively (Epstein and Buhovac, 2010, p. 313).

In our view it is crucial how the analysis of social intervention dynamics and the registration of (lacking) impacts improvement are combined in feedback X. Most of the reviewed researchers do refer to this to some extent (Baumgartner, 2014, p. 264; Epstein and Buhovac, 2010, pp. 307; 309; Hahn et al., 2015, p. 303; Maon et al., 2009, p. 83; Searcy, 2014, pp. 10; 12). Hahn et al., for example, emphasize attention to tensions due to the changes that corporate sustainability calls for and suggest various strategies to deal with these intra-organisational tensions (Hahn et al., 2015, p. 305). Baumgartner calls for a reflection on all sustainability dimensions (i.e. social and physical dimensions), their impacts (i.e. PPP in time and place), and their interrelations in order to develop a comprehensive corporate sustainability strategy, based on these cultural differences between organisations (Baumgartner, 2014, p.264). Others also provide useful socio-cultural typologies of companies and relate this to the level of success in realizing change (Linnenluecke and Griffiths, 2010, p. 359; Van Marrewijk, 2004a). These typologies may be useful in finding explanations in the social dynamics for success and failures and the appropriateness of specific social interventions.

In transformative learning such an analysis would result in feedback Y: adjusting visions, mission and goals. Some scholars have made steps in this direction. Maon and Lindgreen built their approach around the need to regularly unfreeze institutionalized practices and include their step 8: "evaluations should be based on measuring, verifying, and reporting, with the objectives of determining what works well, why, and how to ensure it will continue; investigating what is not working well and why; exploring barriers to success and ways to overcome them; and revisiting original goals or establishing new ones as necessary" (Maon et al., 2009, p. 83), but they do not further elaborate this.
Finally feedback $\mathrm{X}$ and $\mathrm{Y}$ should also lead to adjusted intervention strategies (feedback $Z$ ). This we only find to some extent in the approach in Asif et al., where they promote the assessment of CS integration in structures and routines and checking for learning from past experiences (Asif et al., 2011, pp. 361-363), however, they do not provide tools to analyse these learning processes. The same can be seen in (Lindgreen and Swaen, 2010; Maon et al., 2009).

The table clarifies that the separate elements of the full transformative learning approach are present in recent literature, but that the combined application of the three feedbacks in the CS approach is not yet presented. We see proposals of some useful elements. The various typologies of organisational culture are useful to describe key features of the social dynamics inside firms (Linnenluecke and Griffiths, 2010, p. 359; Van Marrewijk, 2003b, p. 108), while Baumgartner has given suggestions on how deeper integration of $\mathrm{CS}$ in organisational culture can be analysed (Baumgartner, 2009, p. 109). The listing of possible tensions and opposition against interventions in the organisation is also useful (Hahn et al., 2015, p. 305; Lozano, 2007).

The literature gives examples of working in this direction both with large and medium size companies, in various sectors, making cross comparisons and in the developed world and emerging economies (Johnson and Schaltegger, 2015; Lindgreen et al., 2010, 2009; Luken and Castellanos-Silveria, 2011).

We need to further develop, by synthesising of these various elements, an overarching framework and related methods, which will enable both academic scholars and practitioners to understand the social interventions dynamics. This can best be further developed in a transdisciplinary approach, as engaged scholars and action researchers as suggested by (Schaltegger et al., 2013, p. 226), having various tools and methods elaborated and tested in close collaboration with the type of front running companies, which we referred to in the introduction.

The academic community needs to play an essential double role here: partly supplying such approaches and tools, and partly critically analysing the progress made and testing the assumptions about effective strategies for transformative change. We will set our steps in this direction, but we welcome a wide collaboration with academic and market actors in this common challenge.

\section{References}

Aguinis, H., Glavas, A., 2012. What We Know and Don't Know about corporate social responsibility: a review and research agenda. J. Manage 38, 932-968. http:// dx.doi.org/10.1177/0149206311436079.

Allen, D.T., Rosselot, K.S., 1994. Pollution prevention at the macro scale: flows of wastes, industrial ecology and life cycle analyses. In: Waste Management, pp. 317-328. http://dx.doi.org/10.1016/0956-053X(94)90078-7.

Asif, M., Searcy, C., Zutshi, A., Ahmad, N., 2011. An integrated management systems approach to corporate sustainability. Eur. Bus. Rev. 23, 353-367. http:// dx.doi.org/10.1108/09555341111145744.

Azapagic, A., 2003. Systems approach to corporate sustainability: a general management framework. Process Saf. Environ. Prot. 81, 303-316.

Azapagic, A., 2004. Developing a framework for sustainable development indicators for the mining and minerals industry. J. Clean. Prod. 12, 639-662. http:// dx.doi.org/10.1016/S0959-6526(03)00075-1.

Azapagic, A., Perdan, S., 2003. Managing corporate social responsibility: translating theory into business practice. Int. J. Corp. Sustain 44, 97-108.

Azapagic, A., Perdan, S., 2005a. An integrated sustainability decision-support framework Part I: problem structuring. Int. J. Sustain. Dev. World Ecol. 12, 98-111.

Azapagic, A., Perdan, S., 2005b. An integrated sustainability decision-support framework Part II: problem analysis. Int J. Sustain. Dev. World Ecol. 12 112-131. http://dx.doi.org/10.1080/13504500509469623.

Baas, L., 1998. Cleaner production and industrial ecosystems, a Dutch experience. J. Clean. Prod. 6, 189-197. http://dx.doi.org/10.1016/S0959-6526(98)00015-8.

Baas, L., 2007. To make zero emissions technologies and strategies become a reality, the lessons learned of cleaner production dissemination have to be known. J. Clean. Prod. 15, 1205-1216. http://dx.doi.org/10.1016/j.jclepro.2006.07.017. 
Bansal, P., DesJardine, M.R., 2014. Business sustainability: It is about time. Strateg. Organ 12, 70-78. http://dx.doi.org/10.1177/1476127013520265.

Bartholomew, K.M., Lindsey, T.C., Sparks, J.O., McKinley, D., 2008. Multi-state initiative to enhance pollution prevention technology diffusion using the ADOP2T model. J. Clean. Prod. 16, 686-692. http://dx.doi.org/10.1016/ j.jclepro.2007.02.019.

Baumgartner, R.J., 2009. Organizational culture and leadership: preconditions for the development of a sustainable corporation. Sustain. Dev. 17, 102-113. http:// dx.doi.org/10.1002/sd.405.

Baumgartner, R.J., 2014. Managing corporate sustainability and CSR: a conceptual framework combining values, strategies and instruments contributing to sustainable development. Corp. Soc. Responsib. Environ. Manag. 21, 258-271. http://dx.doi.org/10.1002/csr.1336.

Baumgartner, R.J., Ebner, D., 2010. Corporate sustainability strategies: sustainability profiles and maturity levels. Sustain. Dev. 18, 76-89. http://dx.doi.org/10.1002/ sd. 447.

Bebbington, J., Brown, J., Frame, B., 2007. Accounting technologies and sustainability assessment models. Ecol. Econ. 61, 224-236. http://dx.doi.org/10.1016/ j.ecolecon.2006.10.021.

Birkin, F., Polesie, T., Lewis, L., 2009. A new business model for sustainable development: an exploratory study using the theory of constraints in Nordic organizations. Bus. Strateg. 290, 277-290. http://dx.doi.org/10.1002/bse.

Boons, F., Lüdeke-Freund, F., 2013. Business models for sustainable innovation: state-of-the-art and steps towards a research agenda. J. Clean. Prod. 45, 9-19. http://dx.doi.org/10.1016/j.jclepro.2012.07.007.

Bootsma, M.C., Vermeulen, W.J.V., Van Dijk, J., Schot, P.P., 2014. Added value and constraints of transdisciplinary case studies in environmental science curricula. Corp. Soc. Responsib. Environ. Manag. 21, 155-166. http://dx.doi.org/10.1002/ csr.1314.

Bowen, H., 1953. Social Responsibilities of the Businessman. Harper \& Row, New York.

Braungart, M., McDonough, W., Bollinger, A., 2007. Cradle-to-cradle design: creating healthy emissions - a strategy for eco-effective product and system design. J. Clean. Prod. 15, 1337-1348. http://dx.doi.org/10.1016/j.jclepro.2006.08.003.

Bu, M., Liu, Z., Wagner, M., Yu, X., 2013. Corporate social responsibility and the pollution haven hypothesis: evidence from multinationals' investment decision in China. Asia-Pacific J. Acc. Econ. 20, 85-99. http://dx.doi.org/10.1080/ 16081625.2013 .759175$.

Burke, L., Logsdon, J.M., 1996. How corporate social responsibility pays off. Long. Range Plann 29, 495-502. http://dx.doi.org/10.1016/0024-6301(96)00041-6.

Burns, S., 1999. The natural step: a compass for environmental management systems. Corp. Environ. Strateg. 6, 329-342. http://dx.doi.org/10.1016/S10667938(00)80049-4.

Cagno, E., Trucco, P., Tardini, L., 2005. Cleaner production and profitability: analysis of 134 industrial pollution prevention (P2) project reports. J. Clean. Prod. 13, 593-605. http://dx.doi.org/10.1016/j.jclepro.2003.12.025.

Calcott, P., 2010. Mandated self-regulation: the danger of cosmetic compliance. J. Regul. Econ. 38, 167-179. http://dx.doi.org/10.1007/s11149-010-9124-1.

Callicott, J.B., 2005. Animal liberation and environmental ethics: back together again. In: Environmental Philosophy: from Animal Rights to Radical Ecology, pp. $130-138$.

Carroll, A.B., 1978. Setting operational goals for corporate social responsibility. Long. Range Plann 11, 35-38. http://dx.doi.org/10.1016/0024-6301(78)90113-9.

Carroll, A., 1979. A three-dimensional conceptual model of corporate performance. Acad. Manag. Rev. 4, 497-505. http://dx.doi.org/10.2307/257850.

Carroll, A.B., 1987. In search of the moral manager. Bus. Horiz. 30, 7-15. http:// dx.doi.org/10.1016/0007-6813(87)90002-4.

Carroll, A.B., 1991. The pyramid of corporate social responsibility: toward the moral management of organizational stakeholders. Bus. Horiz. 34, 39-48. http:// dx.doi.org/10.1016/0007-6813(91)90005-G.

Carroll, A.B., 1999. Corporate social responsibility: evolution of a definitional construct. Bus. Soc. 38, 268-295. http://dx.doi.org/10.1177/ 000765039903800303.

Chouinard, Y., Ellison, J., Ridgeway, R., 2011. The big idea : the sustainable economy. Harv. Bus. Rev 1-7. http://dx.doi.org/10.1111/j.1365-2214.2011.01330.x.

Christmann, P., Taylor, G., 2002. Globalization and the environmental: strategies for international voluntary environmental initiatives. Acad. Manag. 16, 121-135.

Cole, M.A., 2004. Trade, the pollution haven hypothesis and the environmental Kuznets curve: examining the linkages. Ecol. Econ. 48, 71-81. http://dx.doi.org/ 10.1016/j.ecolecon.2003.09.007.

Cramer, J., 2005a. Experiences with structuring corporate social responsibility in Dutch industry. J. Clean. Prod. 13, 583-592. http://dx.doi.org/10.1016/ j.jclepro.2003.12.008.

Cramer, J., 2005b. Company learning about corporate social responsibility. Bus. Strateg. Environ. 14, 255-266. http://dx.doi.org/10.1002/bse.432.

Curkovic, S., Sroufe, R., 2011. Using ISO 14001 to promote a sustainable supply chain strategy. Bus. Strateg. Environ. 20, 71-93.

Davis, K., 1975. Five propositions for social responsibility. Bus. Horiz. 18, 19-24. http://dx.doi.org/10.1016/0007-6813(75)90048-8.

Delmas, M., 2002. The diffusion of environmental management standards in Europe and in the United States: an institutional perspective. Policy Sci. 91-119.

Delmas, M., 2003. In: Search of ISO: an Institutional Perspective on the Adoption of International Management Standards, Policy.

Delmas, M., Toffel, M., 2008. Organizational responses to environmental demands: opening the black box. Strateg. Manag. J. 29, 1027-1055.
Dicken, P., 2015. Global Shift: Mapping the Changing Contours of the World Economy, Booksgooglecom. Guilford Publications.

Doorman, F., 2012. Crisis, Economics, and the Emperor's Clothes. Lulu Internet Publishers.

Du Pisani, J. a., 2006. Sustainable development - historical roots of the concept Environ. Sci. 3, 83-96. http://dx.doi.org/10.1080/15693430600688831.

Durfee, M., 1999. Diffusion of pollution prevention policy. Ann. Am. Acad. Pol. Soc. Sci. 566, 108-119. http://dx.doi.org/10.1177/0002716299566001009.

Dyllick, T., Hockerts, K., Thomas Dyllick, K.H., 2002. Beyond the business case for corporate sustainability. Bus. Strateg. Environ. 11, 130-141. http://dx.doi.org 10.1002 /bse.323.

Eccles, R.G., Ioannou, I., Serafeim, G., 2014. The impact of corporate sustainability on organizational processes and performance. Manage. Sci. 60, 2835-2857. http:// dx.doi.org/10.1287/mnsc.2014.1984.

EEA, 2015. The European Environment - State and Outlook 2015. synthesis report, Copenhagen.

Epstein, M.J., Buhovac, A.R., 2010. Solving the sustainability implementation challenge. Organ. Dyn. 39, 306-315. http://dx.doi.org/10.1016/j.orgdyn.2010.07.003.

Epstein, M.J., Roy, M.-J., 2001. Sustainability in action: identifying and measuring the key performance drivers. Long. Range Plann 34, 585-604. http://dx.doi.org/ 10.1016/S0024-6301(01)00084-X.

Eskeland, G.S., Harrison, A.E., 2003. Moving to greener pastures? Multinationals and the pollution haven hypothesis. J. Dev. Econ. 70, 1-23. http://dx.doi.org/ 10.1016/S0304-3878(02)00084-6.

European Commision, 2006. Implementing the Partnership for Growth and Jobs Making Europe a Pole of Excellence on CSR. European Commision. COM(2006) 136 final.

European Commission, 2001. Green Paper - Promoting a European Framework for Corporate Social Responsibility. European Commission, Brussels.

European Commission, 2002. The World Summit on Sustainable Development People, Planet, Prosperity (Luxembourg).

European Multistakeholder Forum on CSR, 2004. European Multistakeholder Forum on CSR. Final Results \& Recommendations, p. 131.

Figge, F., Hahn, T., Schaltegger, S., Wagner, M., 2002. The sustainability balanced scorecard - management to business strategy. Bus. Strateg. Environ. 11, 269-284. http://dx.doi.org/10.1002/bse.339.

Frederick, W.C., 1960. The growing concern over business responsibility. Calif. Manage. Rev. 2, 54-61.

Frederick, W.C., 1994. From CSR1 to CSR2: the maturing of business-and-society thought. Bus. Soc. 33, 150-164. http://dx.doi.org/10.1177 000765039403300202.

Gallup, J., Marcotte, B., 2004. An assessment of the design and effectiveness of the environmental pollution prevention Project (EP3). J. Clean. Prod. 12, 215-225. http://dx.doi.org/10.1016/S0959-6526(03)00097-0.

Glavič, P., Lukman, R., 2007. Review of sustainability terms and their definitions. J. Clean. Prod. 15, 1875-1885. http://dx.doi.org/10.1016/j.jclepro.2006.12.006.

Graedel, T.E., 1996. On the concept of industrial Ecology. Annu. Rev. Energy Environ. 21, 69-98. http://dx.doi.org/10.1146/annurev.energy.21.1.69.

Granek, F., 2011. Business value of toxics reduction and pollution prevention planning. J. Clean. Prod. 19, 559-560. http://dx.doi.org/10.1016 j.jclepro.2010.09.012.

Gravitis, J., 2007. Zero techniques and systems - ZETS strength and weakness. J. Clean. Prod. 15, 1190-1197. http://dx.doi.org/10.1016/j.jclepro.2006.07.038.

Grether, J.-M., Mathys, N.A., de Melo, J., 2012. Unravelling the worldwide pollution haven effect. J. Int. Trade Econ. Dev. 21, 131-162. http://dx.doi.org/10.1080/ 09638190903552040

Haberl, H., Fischer-Kowalski, M., Krausmann, F., Martinez-Alier, J., Winiwarter, V., 2011. A socio-metabolic transition towards sustainability? Challenges for another great Transformation. Sustain. Dev. 19, 1-14. http://dx.doi.org/10.1002/sd.410.

Haddock-Fraser, J., 2012. The role of the news media in influencing corporate environmental sustainable development: an alternative methodology to assess stakeholder engagement. Corp. Soc. Responsib. Environ. Manag. 19, 327-342. http://dx.doi.org/10.1002/csr.282.

Hahn, T., Scheermesser, M., 2006. Approaches to corporate sustainability among German companies. Corp. Soc. Responsib. Environ. Manag 13, 150-165. http:/ dx.doi.org/10.1002/csr.100.

Hahn, T., Pinkse, J., Preuss, L., Figge, F., 2015. Tensions in corporate sustainability: towards an integrative framework. J. Bus. Ethics 127, 297-316. http:/ dx.doi.org/10.1007/s10551-014-2047-5.

Halonen, T., Mkapa, B.W., 2004. A Fair Globalization: Creating Opportunities for All, International Labour Organization. http://dx.doi.org/10.1080 14747730500202255 .

Hammond, G.P., 2006. People, planet and prosperity: the determinants of humanity's environmental footprint. Nat. Resour. Forum 30, 27-36. http:// dx.doi.org/10.1111/j.1477-8947.2006.00155.x.

Haney, L.H., 1920. History of Economic Thought: a Critical Account of the Origin and Development of the Economic Theories of the Leading Thinkers in the Leading Nations. Macmillan, New York. Revised, Page iii by Lewis H. Haney. | Online Research Library: Questia.

Hart, S.L., Milstein, M.B., 2003. Creating sustainable value. Acad. Manag. Exec. 17, 56-67. http://dx.doi.org/10.5465/AME.2003.10025194.

Holmberg, J., Robèrt, K.H., 2000. Backcasting - a framework for for strategic planning. Int. J. Sustain. Dev. World Ecol. 7, 291-308.

Holme, R., Watts, P., 2000. Corporate social responsibility: making good business sense. World Bus. Counc. Sustain. Dev. 1-18. 
Howie, P., Bagnall, R., 2015. A critical comparison of transformation and deep approach theories of learning. Int. J. Lifelong Educ. 1-18. http://dx.doi.org/ $10.1080 / 02601370.2014 .1000409$.

Hunt, E.K., Lautzenheiser, M., 2011. History of Economic Thought a Critical Perspective. M.E. Sharpe, New York.

IISD, n.d. Compendium of sustainable Development Indicator Initiatives [WWW Document]. URL https://www.iisd.org/measure/compendium/(accessed 5.11.15.).

ISEAL Alliance, 2013. ISEAL Code of Good Practice for Setting Social and Environmental Standards. Version 5.1, vol. 44, pp. 1-22.

ISO, 2004. ISO 14001 Environmental Management Systems - Requirements with Guidance for Use (ISO 14001:2004, IDT). NEN, Delft, The Netherlands.

ISO, 2010. ISO 26000:10 Guidance on Social Responsibility. NEN, Delft, The Netherlands.

ISO, 2013. The ISO Survey of Management System Standard Certifications - 2012 Executive Summary.

ISO, GRI, 2014. GRI G4 Guidelines and ISO 26000: 2010 How to Use the GRI G4 Guidelines and ISO 26000 in Conjunction (Geneva).

ISSC, UNESCO, 2013. World Social Science Report 2013-Changing Global Environments (Paris).

ITC, 2011. The Impacts of Private Standards on Producers in Developing Countries: Literature Review Series on the Impacts of Private Standards - Part II. In: International Trade Centre Technical Series doi:42117.

Johnson, M.P., Schaltegger, S., 2015. Two decades of sustainability management tools for SMEs: how far have We Come? J. Small Bus. Manag. 1-25. http:/ dx.doi.org/10.1111/jsbm.12154.

Keijzers, G., 2000. The evolution of Dutch environmental policy: the changing ecological arena from 1970-2000 and beyond. J. Clean. Prod. 8, 179-200.

Kerr, I.R., 2006. Leadership strategies for sustainable SME operation. Bus. Strateg. Environ. 15, 30-39. http://dx.doi.org/10.1002/bse.451.

Kitchenham, A., 2008. The evolution of John Mezirow's transformative learning theory. J. Transform. Educ. 6, 104-123. http://dx.doi.org/10.1177 1541344608322678.

KPMG, 2013. The KPMG Survey of Corporate Responsibility Reporting 2013.

Kuehr, R., 2007. Towards a sustainable society: united nations University's zero emissions approach. J. Clean. Prod. 15, 1198-1204. http://dx.doi.org/10.1016/ j.jclepro.2006.07.020.

Lee, M.-D.P., 2008. A review of the theories of corporate social responsibility: Its evolutionary path and the road ahead. Int. J. Manag. Rev. 10, 53-73. http:// dx.doi.org/10.1111/j.1468-2370.2007.00226.x.

Leisinger, K., Bakker, P., 2013. The Key Challenges to 2030/2050: Mapping Out Longterm Pathways to Sustainability and Highlighting Solutions that Should Be Scaled up.

Lenzen, M., Kanemoto, K., Moran, D., Geschke, A., 2012a. Mapping the structure of the world economy. Environ. Sci. Technol. 46, 8374-8381. http://dx.doi.org 10.1021/es300171x

Lenzen, M., Moran, D., Kanemoto, K., Foran, B., Lobefaro, L., Geschke, A., 2012b. International trade drives biodiversity threats in developing nations. Nature 486, 109-112. http://dx.doi.org/10.1038/nature11145.

Levinson, A., Taylor, M.S., 2008. Unmasking the pollution Haven effect. Int. Econ. Rev. 49, 223-254 (Philadelphia).

Lindgreen, A., Swaen, V., 2010. Corporate social responsibility. Int. J. Manag. Rev. 12 1-7. http://dx.doi.org/10.1111/j.1468-2370.2009.00277.x.

Lindgreen, A., Swaen, V., Johnston, W.J., 2009. Corporate social responsibility: an empirical investigation of U.S. organizations. J. Bus. Ethics 85, 303-323. http: dx.doi.org/10.1007/s10551-008-9738-8.

Lindgreen, A., Córdoba, J.-R., Maon, F., Mendoza, J.M., 2010. Corporate social responsibility in Colombia: making sense of social strategies. J. Bus. Ethics 91 229-242. http://dx.doi.org/10.1007/s10551-010-0616-9.

Linnenluecke, M.K., Griffiths, A., 2010. Corporate sustainability and organizational culture. J. World Bus. 45, 357-366. http://dx.doi.org/10.1016/ j.jwb.2009.08.006.

Linnenluecke, M.K., Russell, S.V., Griffiths, A., 2009. Subcultures and sustainability practices: the impact on understanding corporate sustainability. Bus. Strateg. Environ. 18, 432-452. http://dx.doi.org/10.1002/bse.609.

Lovelock, J., 2003. Gaia: the living Earth. Nature 426, 769-770. http://dx.doi.org $10.1038 / 426769$

Lozano, R., 2007. Orchestrating organisational changes for corporate sustainability Greener Manag. Int. 57, 43-64. http://dx.doi.org/10.9774/GLEAF.3062.2007.sp. 00005.

Lozano, R., 2008. Envisioning sustainability three-dimensionally. J. Clean. Prod. 16, 1838-1846. http://dx.doi.org/10.1016/j.jclepro.2008.02.008.

Lozano, R., 2012. Towards better embedding sustainability into companies' systems: an analysis of voluntary corporate initiatives. J. Clean. Prod. 25, 14-26. http:/ dx.doi.org/10.1016/j.jclepro.2011.11.060.

Lozano, R., Huisingh, D., 2011. Inter-linking issues and dimensions in sustainability reporting. J. Clean. Prod. 19, 99-107. http://dx.doi.org/10.1016 j.jclepro.2010.01.004.

Luken, R., Castellanos-Silveria, F., 2011. Industrial transformation and sustainable development in developing countries. Sustain. Dev. 19, 167-175. http:/ dx.doi.org/10.1002/sd.434.

MacDonald, J.P., 2005. Strategic sustainable development using the ISO 14001 Standard. J. Clean. Prod. 13, 631-643. http://dx.doi.org/10.1016/j.jclepro.2003.06.001.

Maon, F.F., Lindgreen, A., Swaen, V., 2009. Designing and implementing corporate social responsibility: an integrative framework grounded in theory and practice. J. Bus. Ethics 87, 71-89. http://dx.doi.org/10.1007/s10551-008-9804-2.
Melnyk, S.A., Sroufe, R.P., Calantone, R., 2003. Assessing the impact of environmental management systems on corporate and environmental performance. J. Oper. Manag. 21, 329-351. http://dx.doi.org/10.1016/S0272-6963(02)00109-2.

Miller, G., Burke, J., McComas, C., Dick, K., 2008. Advancing pollution prevention and cleaner production - USA's contribution. J. Clean. Prod. 16, 665-672. http:/ dx.doi.org/10.1016/j.jclepro.2007.02.013.

Moen, R., Norman, C., 2006. Evolution of the PDCA Cycle (Detroit).

Montiel, I., 2008. Corporate social responsibility and corporate sustainability: separate pasts, common futures. Organ. Environ 21, 245-269. http://dx.doi.org/ $10.1177 / 1086026608321329$.

Morrow, D., Rondinelli, D., 2002. Adopting corporate environmental management systems: motivations and results of ISO 14001 and EMAS Certification. Eur. Manag. J. 20, 159-171. http://dx.doi.org/10.1016/S0263-2373(02)00026-9.

Moura-Leite, R.C., Padgett, R.C., 2011. Historical background of corporate social responsibility. Soc. Responsib. J. 7, 528-539. http://dx.doi.org/10.1108/ 1747111111117511.

Nijdam, D.S., Wilting, H.C., Goedkoop, M.J., Madsen, J., 2008. Environmental load from dutch private consumption: how much damage takes place abroad? J. Ind. Ecol. 9, 147-168. http://dx.doi.org/10.1162/1088198054084725.

Ochsner, M., Chess, C., Greenberg, M., 1995. Pollution prevention at the 3M corporation: case study insights into organizational incentives, resources, and strategies. Waste Manag. 15, 663-672. http://dx.doi.org/10.1016/0956-053X(96)00047-5.

Parris, T.M., Kates, R.W., 2003. Characterizing a sustainability transition: goals, targets, trends, and driving forces. Proc. Natl. Acad. Sci. U. S. A. 100, 8068-8073. http://dx.doi.org/10.1073/pnas.1231336100.

Pauli, G., 2010. The Blue Economy: 10 Years - 10 Innovations - 100 Million Jobs. Academic Foundation.

Petkoski, D., Twose, N., 2003. Public Policy for Corporate Social Responsibility, WBI Series on Corporate Responsibility, Accountability, and Sustainable Compatitiveness.

Pojasek, R.B., 2012. Implementing a sustainability management system. Environ. Qual. Manag. 22, 83-90. http://dx.doi.org/10.1002/tqem.21319.

Polonsky, M., Jevons, C., 2009. Global branding and strategic CSR: an overview of three types of complexity. Int. Mark. Rev. 26, 327-347. http://dx.doi.org/ 10.1108/02651330910960816.

Porter, M.E., 1991. America's green strategy. Sci. Am. 264, 168.

Porter, M., Kramer, M., 2006. Strategy and society. Harv. Bus. Rev. 1-15.

Porter, M., Kramer, M., 2011a. Creating shared value - how to reinvent capitalism and unleash a wave of innovation and growth. Harv. Bus. Rev 39, 62-77. http:// dx.doi.org/10.1108/09600039410055963.

Porter, M.E., Kramer, M.R., 2011b. The big idea: creating shared value. Harv. Bus. Rev. 89 http://dx.doi.org/10.2469/dig.v41.n1.28.

Potts, J., Lynch, M., Wilkings, A., Huppe, G., Cunningham, M., Voora, V., 2014. The State of Sustainability Initiatives Review 2014 Standards and the Green Economy (Winnipeg).

Robèrt, K.-H., 2000. Tools and concepts for sustainable development, how do they relate to a general framework for sustainable development, and to each other? J. Clean. Prod. 8, 243-254. http://dx.doi.org/10.1016/S0959-6526(00)00011-1.

Robèrt, K.H., Schmidt-Bleek, B., Aloisi De Larderel, J., Basile, G., Jansen, J.L., Kuehr, R., Price Thomas, P., Suzuki, M., Hawken, P., Wackernagel, M., 2002. Strategic sustainable development - selection, design and synergies of applied tools. J. Clean. Prod. 10, 197-214. http://dx.doi.org/10.1016/S0959-6526(01)00061-0.

Robinson, J., 2004. Squaring the circle? Some thoughts on the idea of sustainable development. Ecol. Econ. 48, 369-384. http://dx.doi.org/10.1016/ j.ecolecon.2003.10.017.

Rockström, J., Steffen, W., Noone, K., Persson, Å., Chapin, F.S., Lambin, E., Lenton, T.M., Scheffer, M., Folke, C., Schellnhuber, H.J., Nykvist, B., de Wit, C.a., Hughes, T., van der Leeuw, S., Rodhe, H., Sörlin, S., Snyder, P.K., Costanza, R., Svedin, U., Falkenmark, M., Karlberg, L., Corell, R.W., Fabry, V.J., Hansen, J., Walker, B., Liverman, D., Richardson, K., Crutzen, P., Foley, J., 2009. Planetary boundaries: Exploring the safe operating space for humanity. Ecol. Soc 14 472-475. http://dx.doi.org/10.1038/461472a.

Rourke, D.O., 2005. Market movements nongovernmental organization strategies consumption. J. Ind. Ecol. 9, 115-128.

Schaltegger, S., Beckmann, M., Hansen, E.G., 2013. Transdisciplinarity in corporate sustainability: mapping the field. Bus. Strateg. Environ. 22, 219-229. http:// dx.doi.org/10.1002/bse.1772.

Schrader, C., Freimann, J., Seuring, S., 2012. Business strategy at the base of the pyramid. Bus. Strateg. Environ. 21, 281-298. http://dx.doi.org/10.1002/bse.727.

Searcy, C., 2011. Updating corporate sustainability performance measurement systems. Meas. Bus. Excell 15, 44-56. http://dx.doi.org/10.1108/ 13683041111131619 .

Searcy, C., 2014. Measuring enterprise sustainability. Bus. Strateg. Environ. http:// dx.doi.org/10.1002/bse.1861.

Sewell, W.H.J., 1992. A theory of structure: duality, agency, and transformation. Am. J. Sociol. 98, 1-29.

Smith, A., 1759. In: Jonat (Ed.), The Theory of Moral Sentiments, 2010.

Steger, U., 2000. Management systems: empirical evidence and further perspectives. Eur. Manag. J. 18, 23-37.

Stevenson, R.S., 2004. An assessment of the design and effectiveness of the ASEAN Environmental improvement Program. J. Clean. Prod. 12, 227-236. http:// dx.doi.org/10.1016/S0959-6526(03)00096-9.

Székely, F., Knirsch, M., 2005. Responsible leadership and corporate social responsibility. Eur. Manag. J. 23, 628-647. http://dx.doi.org/10.1016/ j.emj.2005.10.009. 
2832

W.J.V. Vermeulen, S. Witjes / Journal of Cleaner Production 112 (2016) 2822-2832

Tinsley, S., 2002. Strategy Lev. 390, 376-390.

Tukker, A., Emmert, S., Charter, M., Vezzoli, C., Str, E., Munch Andersen, M. Geerken, T., Tischner, U., Lahlou, S., 2008. Fostering change to sustainable consumption and production: an evidence based view. J. Clean. Prod. 16, 1218-1225. http://dx.doi.org/10.1016/j.jclepro.2007.08.015.

UNEP, 2011a. Towards a Green Economy: Pathways to Sustainable Development and Poverty Eradication, Sustainable Development. http://dx.doi.org/10.1063/1.3159605.

UNEP, 2011b. Towards a Green Economy: Pathways to Sustainable Development and Proverty Eradication. A Synthesis for Policy Makers. www.unep.org/ greeneconomy (Nairobi).

United Nations Environment Programme, 2007. Sustainable Consumption and Production in South East Europe and Eastern Europe, Caucasus and Central Asia, pp. $2-188$.

Van Berkel, R., 2007. Cleaner production and eco-efficiency initiatives in Western Australia 1996-2004. J. Clean. Prod. 15, 741-755. http://dx.doi.org/10.1016/ j.jclepro.2006.06.012.

Van der Heijden, A., Driessen, P.P.J., Cramer, J.M., 2010. Making sense of corporate social responsibility: exploring organizational processes and strategies. J. Clean. Prod. 18, 1787-1796. http://dx.doi.org/10.1016/j.jclepro.2010.07.024.

Van Marrewijk, M., 2003a. Concepts and definitions of CSR and corporate surtainability: between agency and communion. J. Bus. Ethics 44, 95-105. http:// dx.doi.org/10.2307/25075020.

Van Marrewijk, M., 2003b. J. Bus. Ethics 44, 107-119. http://dx.doi.org/10.1023/A: 1023383229086.

Van Marrewijk, M., 2004a. A value based approach to organization types: towards a coherent set of stakeholder - oriented management tools. J. Bus. Ethics 55, 147-158. http://dx.doi.org/10.1007/s10551-004-1898-6.

Van Marrewijk, M., 2004b. The social dimension of organizations: recent experences with great palce to work assessment practices. J. Bus. ethics 55, 135-146.
Vermeulen, W.J.V.V., 2006. The social dimension of industrial ecology: on the inplications of the inherent nature of social phenomena. Prog. Ind. Ecol. 3, 574. http://dx.doi.org/10.1504/PIE.2006.012754.

Vermeulen, W.J.V., 2010. Sustainable supply chain governance systems: conditions for effective market based governance in global trade. Prog. Ind. Ecol. 7, 138. http://dx.doi.org/10.1504/PIE.2010.036046.

Vermeulen, W.J.V., 2015. Self-governance for sustainable global Supply chains: can it deliver the impacts needed? Bus. Strateg. Environ. 24, 73-85. http:// dx.doi.org/10.1002/bse.1804.

van Ahsen, A., 2014. The integration of quality, environmental and health and safety management by car manufacturers - a long-term empirical Study. Bus. Strateg. Environ 23, 395-416. http://dx.doi.org/10.1002/bse.1791.

Watts, P., Holmes, Lord, 1998. Corporate Social Responsibility: Marking Expectatrons Meet, World Business Council for Sustainability Development. WBCSD, Geneva.

WBCSD, 2010a. Vision 2050: the New Agenda for Business. WBCSD, Geneva. WBCSD, 2010b. Pathway toward a Sustainable 2050: Mural.

WBCSD, World Business Council for Sustainable Development, Council, W.B., Development, S., 2010. Vision 2050: the New Agenda for Business. WBCSD, Geneva.

World Commission on Environment and Development, 1987. Our Common Future. http://dx.doi.org/10.1080/07488008808408783 (The Brundtland Report)

Yin, H., Schmeidler, P.J., 2009. Why do standardized ISO 14001 environmental management systems lead to heterogeneous environmental outcomes? Bus. Strateg. Environ. 18, 469-486. http://dx.doi.org/10.1002/bse.629.

Zorpas, A., 2010. Environmental management systems as sustainable tools in the way of life for the SUEs and VSMEs. Bioresour. Technol. 101, 1544-1557. http:// dx.doi.org/10.1016/j.biortech.2009.10.022. 